\title{
Synthesis and Characterization of Nano-sized Carbonated Calcium Hydroxyapatite (CHAp) from Rebon shrimp (Acetes erythraeus) as a Candidate for Dental Restoring Application
}

\author{
Ngatijo $^{1}$, Restina Bemis ${ }^{1 *}$, Heriyanti ${ }^{1}$, Rahmi $^{1}$, Nashih Ulwan ${ }^{1}$, Rahmat Basuki $^{2}$ \\ ${ }^{1}$ Departement of Chemistry, Faculty of Science and Technology, Universitas Jambi \\ Jl. Jambi-Ma Bulian Km. 15, Mendalo Darat, Jambi, 36361, Indonesia \\ ${ }^{2}$ Department of Chemistry, Faculty of Military Mathematics and Natural Sciences, Universitas Pertahanan RI \\ Kawasan IPSC Sentul, Bogor, Jawa Barat, 16810, Indonesia \\ *Corresponding author: restina@unja.ac.id
}

Received: June 2021; Revision: October 2021; Accepted: October 2021; Available online: November 2021

\begin{abstract}
Carbonated calcium hydroxyapatite (CHAp) exhibits excellent biocompatibility with bone and teeth, making it an ideal candidate for orthopedic and dental application. However, the study of CHAp synthesis from natural material is still scarce. The purpose of this research is to synthesize and characterize of CHAp, using Rebon shrimp (Acetes erythraeus) as a calcium source. The synthesis was conducted by hydrothermal method with the variation of $\mathrm{Ca} / \mathrm{P}$ ratios $1.61 ; 1.67 ; 1.73$. The as-prepared CHAp was characterized by Fourier transform infrared spectroscopy (FT-IR), X-ray diffraction (XRD), and scanning electron microscopy-energy dispersive X-ray (SEM-EDX). The FT-IR results show that synthesized material exhibited characteristic CHAp band of hydroxide at 3448 and $1635 \mathrm{~cm}^{-1}$, carbonate at 872 and $1427 \mathrm{~cm}^{-1}$, and phosphate at 1049; 606; and $570 \mathrm{~cm}^{-1}$. The diffractogram pattern assigned the all observed peak of CHAp are in good agreement compared to CHAp database with the nano-scale size. It also observed that the high $\mathrm{Ca} / \mathrm{P}$ ratio will decrease the crystallinity of CHAp. The as-prepared CHAp micrograph is agglomerates spherical form with size between 5-20 nm which build up from 18-26 nm crystallite particles. The result of this research confirmed that Rebon shrimp is the promising materials for calcium source in CHAp production.
\end{abstract}

Keywords: Dental restoring candidate material, Carbonated calcium hydroxyapatite (CHAp), Nanoparticles, Calcium Source Rebon shrimp (Acetes erythraeus).

DOI: $10.15408 / j k v . v 7 i 2.21359$

\section{INTRODUCTION}

In present decade, there has been observed a huge progress in the field of dentistry (Deb \& Chana, 2015). Not only from dental techniques and methods of therapy, the progress has been occurred in significant development of biomaterial engineering (Matinlinna, 2013). The science of the biomaterials is consistently increasing due to ingenious modification of previously known materials or completely novel materials for application in dentistry. Bio-glass, biopolymers, bioactive ceramics, and above all, composite materials are the leading directions in the development of dental materials (Vishwakarma et al., 2014).
One of the more immensely studied groups of materials comprises inorganic calcium apatite known as hydroxyapatite (HAp). HAp is grows in hexagonal crystals and naturally occurring as the calcium phosphate minerals (Vallet-Regi, 2014). The color of pure HAP is white and it build up most of the tooth enamel, bone structure, and small amount in part of the human brain (Xie et al., 2012). The first use of synthetic HAp to repair and regenerate bone tissue was reported by Albee (1920), who utilized crystalline HAp to repair surgically induced bone defects in rabbits (LeGeros, 2008). In 1960s, bioceramics based on HAp was begun to greater interest when it seen as biomaterials that possibly induces the reconstruction and repair 
of bone defects (Dorozhkin, 2011). In 1970s, the researchers began to pay attention to the use of HAp in dental surgery (Vallet-Regi, 2014). In particular, the work of Denissen and de Groot in which were used the natural HAp as dental implant (Pajor \& Pajchel, 2019). The research of synthetic HAp has accelerated when it start permanently introduced as dentalrestoring implant in 1980s (Xie et al., 2012). Recently, the composition in HAp structure can be modified to contain carbonate thereby providing a composition more similar to the bone and teeth material (Garskaite et al., 2014; Odusote et al., 2019).

Carbonated calcium hydroxyapatite (CHAp) is found in the mineral component of natural bones and teeth and when the concentration of $\mathrm{CO}_{3}{ }^{2-}$ ions in the HAp lattice is in the range of 3-8 $\mathrm{wt} \%$ (Garskaite et al., 2014). The $\mathrm{OH}^{-}$or $\mathrm{PO}_{4}{ }^{3-}$ group can be replaced by the $\mathrm{CO}_{3}{ }^{2-}$, leading the $\mathrm{A}$ - or B-type of CHAp, respectively. The chemical formula for A-type CHAp has been defined as $\mathrm{Ca}_{10}\left(\mathrm{PO}_{4}\right)_{6}(\mathrm{OH})_{2-2 \mathrm{y}}\left(\mathrm{CO}_{3}\right)_{\mathrm{y}}$, where $0 \leq \mathrm{y} \leq 1$, while for the B-type $\mathrm{Ca}_{10-\mathrm{x}}\left(\mathrm{PO}_{4}\right)_{6 \text { - }}$ ${ }_{\mathrm{x}}\left(\mathrm{CO}_{3}\right)_{\mathrm{x}}(\mathrm{OH})_{2-\mathrm{x}}$, where $0 \leq \mathrm{x} \leq 2$ and sodium ions are located in the calcium sites, inducing a favourable electrical charge balance. The carbonate ion can also replace both of $\mathrm{PO}_{4}{ }^{3-}$ and $\mathrm{OH}^{-}$as AB-type CHAp $\mathrm{Ca}_{10-x}\left(\mathrm{PO}_{4}\right)_{6-}$ ${ }_{x}\left(\mathrm{CO}_{3}\right)_{x}(\mathrm{OH})_{2-x-2 y}\left(\mathrm{CO}_{3}\right)_{y}$ that found in many biological apatites (Garskaite et al., 2014).

The biocompatible, bio-active, and non-toxic character of CHAp makes the materials has highly suitable for dentalrestoring materials (Okada \& Matsumoto, 2015). In general, the manufacturing of synthetic CHAp has been conducted by using several methods: precipitation, sol-gel, hydrothermal, and mechanochemical to solid solution (Sianipar, 2016). The materials used in the manufacture of synthetic CHAp are generally natural substances containing high amount of calcium, such as fish bones, crab shells, shrimp shells, and so forth. Several publications have reported the use of those natural substances as a basic material for synthetic HAP production: clam shell (Sianipar, 2016), fish bone (Anggresani et al., 2021; Hanura et al., 2017), and shrimp shell (Sulistioso et al., 2012). To the best our knowledge there has no publication reported the Rebon shrimp (Acetes erythraeus) from Jambi province as a basic material for synthetic CHAp production.
Jambi province is the abundance of marine animals including the Rebon shrimp (Acetes erythraeus) which found in coastal areas such as in Tanjung Jabung Barat (Tungkal) and Tanjung Jabung Timur (Muaro Sabak) regencies. Rebon shrimp is a type of tiny shrimp whose length ranges from $1-3 \mathrm{~cm}$ with $69.45 \%$ of calcium (Permatasari et al., 2016; Sulistiyono et al., 2017). The high calcium content of Rebon shrimp that has been reported by Sulistiono and Permatasi can be used as a basic material for synthetic CHAp for candidate material in dental-restoring application. This work aims to synthesize the CHAP from Rebon shrimp as a candidate for dental-restoring application. The CHAP synthesis was conducted by the hydrothermal method with the variation of $\mathrm{Ca} / \mathrm{P}$ ratio. The analysis of functional group, crystallinity, composition, surface morphology, and particle size of synthesized CHAP has been deeply discussed in this paper.

\section{MATERIALS AND METHODS Materials}

The Rebon shrimp as the basic materials was obtained from local fisherman in Tanjung Jabung Barat (Tungkal) and Tanjung Jabung Timur (Muaro Sabak) regencies. The reagents used in this study were pro analyst (p.a) grade produced by Merck i.e. $\mathrm{HNO}_{3}$ (aq) $65 \%, \mathrm{NH}_{3}$ (aq) $25 \%$, and $\left(\mathrm{NH}_{4}\right)_{2} \mathrm{HPO}_{4}$ (aq). The $\mathrm{CO}_{2}$ gas produced from PT. AGII, and distilled water produced from G-Force brand.

\section{Instrumentations}

The instruments analysis used were PANalytical Minipal 4 type X-Ray Fluorescence (XRF), Shimadzu Prestige 21 Fourier transform infrared (FTIR), Bruker D2 Phaser X-ray diffraction (XRD), and Phenom Pro X Scanning electron microscopy-energy dispersive X-Ray (SEM-EDX). The preparation tools used in this study were glassware, porcelain dishes, scales, analytical balance, sieve, autoclave, magnetic stirrer, furnace, desiccator, filter paper, aluminum foil, burette, stative, clamp, blender, hot plate, $\mathrm{pH}$ meters, stirring rods, ovens and hydrothermal vessels.

\section{Preparation of precipitated carbonate carbon (PCC)}

A total of $20 \mathrm{~g}$ of dry 100 mesh sieved Rebon shrimp was calcined for 3 hours at a 
temperature of $900{ }^{\circ} \mathrm{C}$ to produce the calcium oxide $(\mathrm{CaO})$. The $\mathrm{CaO}$ powder was allowed to cool in the furnace for 24 hours. The powder was then weighed to get the yield. The preparation of $\mathrm{PCC}$ was conducted by $\mathrm{CaO}$ carbonation method. The process was carried out by dissolving $17 \mathrm{~g}$ of $\mathrm{CaO}$ in $300 \mathrm{~mL}$ of $\mathrm{HNO}_{3} 2 \mathrm{M}$. The mixture was stirred at $250 \mathrm{rpm}$ of magnetic stirring for $30 \mathrm{~min}$ to get the filtrate. The filtrate was heated to $60{ }^{\circ} \mathrm{C}$ and the $\mathrm{pH}$ was set to 12 by carefully addition of $\mathrm{NH}_{4} \mathrm{OH} 25 \%$. The filtrate obtained at the process was flowed by $\mathrm{CO}_{2}$ gas continuously until the $\mathrm{pH}$ becomes 8 . The white solid obtained in this process was filtered and washed with distilled water until the $\mathrm{pH}$ is neutral. The dry solid of 100 mesh powder was labeled as PCC. The PCC powder was analyzed by XRF to determine the \% elemental composition.

\section{Synthesis of CHAp}

The CHAp synthesis was performed by hydrothermal method by Hien et al. (2010) and Azis et al. (2015) through the mixing of $\mathrm{PCC}$ and $\left(\mathrm{NH}_{4}\right)_{2} \mathrm{HPO}_{4}$ saturated solution with a variation of $\mathrm{Ca} / \mathrm{P}$ ratio of $1 / 1.61 ; 1 / 1.67$; and $1 / 1.73$. The mixture was dripped carefully by $\mathrm{NH}_{3}$ (aq) 25\% until pH 11 was reached. This mixture was put into the hydrothermal vessel at $120^{\circ} \mathrm{C}$ for 12 hours reaction time. The CHAp formed was separated from the rest of reactants and then washed by distilled water until the $\mathrm{pH}$ of filtrate was neutral. The synthesized CHAp was dried by $50{ }^{\circ} \mathrm{C}$ heating in oven to remove the water, sieved with 100 mesh sieves, and characterized by the FT-IR, XRD, and SEM.

\section{RESULTS AND DISCUSSION Characterization of PCC}

The synthesis of PCC was carried out using $\mathrm{CaO}$ powder as a calcination product of Rebon shrimp powder as basic materials. The equation for the reaction that occurs can be written as et al., 2015). Elemental analysis result of PCC by XRF (Figure 1) showed that PCC dominated by calcium (70.8\%), phosphor $(12.3 \%)$, and potassium $(4.32 \%)$. The result was in line with the previous work by Sulistiyono et al. (2017).

$\begin{array}{ll}\text { Calcination: } & 2 \mathrm{CaCO}_{3(\mathrm{~s})}+\text { heat } \longrightarrow 2 \mathrm{CaO}_{(\mathrm{s})}+\mathrm{CO}_{2(\mathrm{~g})} \\ \text { Hydration: } & \mathrm{CaO}_{(\mathrm{s})}+2 \mathrm{HNO}_{3(\mathrm{l})} \longrightarrow 2 \mathrm{Ca}\left(\mathrm{NO}_{3}\right)_{2(\mathrm{aq})}+\mathrm{H}_{2} \mathrm{O}_{(\mathrm{l})} \\ & \mathrm{Ca}\left(\mathrm{NO}_{3}\right)_{2(\mathrm{aq})}+2 \mathrm{NH}_{3(\mathrm{l})}+2 \mathrm{H}_{2} \mathrm{O}_{(\mathrm{l})} \longrightarrow \mathrm{Ca}(\mathrm{OH})_{2(\mathrm{aq})}+2 \mathrm{NH}_{4} \mathrm{NO}_{3(\mathrm{aq})} \\ \text { Precipitation: } & \mathrm{Ca}(\mathrm{OH})_{2(\mathrm{aq})}+\mathrm{CO}_{2(\mathrm{~g})} \longrightarrow \mathrm{CaCO}_{3(\mathrm{~s})}+\mathrm{H}_{2} \mathrm{O}_{(\mathrm{l})}\end{array}$

$$
\begin{aligned}
& \mathrm{Ca}\left(\mathrm{NO}_{3}\right)_{2(\mathrm{aq})}+2 \mathrm{NH}_{3(\mathrm{l})}+2 \mathrm{H}_{2} \mathrm{O}_{(\mathrm{l})} \stackrel{\mathrm{Ca}}{\longrightarrow} \mathrm{CaCO}_{3(\mathrm{~s})}+\mathrm{H}_{2} \mathrm{O}_{(\mathrm{l})} \\
& \left.\mathrm{Ca}(\mathrm{OH})_{2(\mathrm{aq})}+\mathrm{CO}_{2(\mathrm{~g})} \longrightarrow \mathrm{OH}\right)_{2(\mathrm{aq})}+2 \mathrm{NH}_{4} \mathrm{NO}_{3(\mathrm{aq})}
\end{aligned}
$$

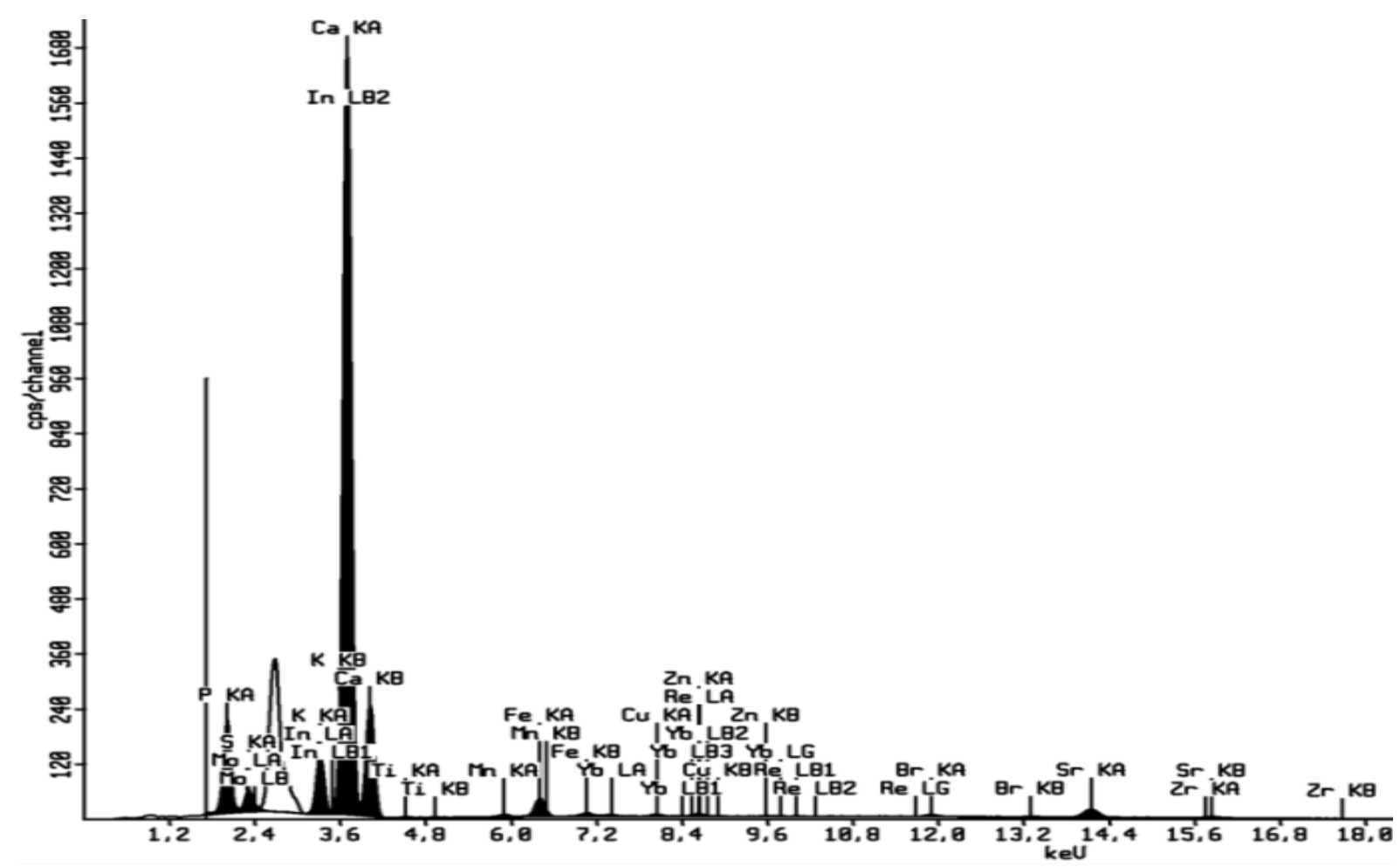

Figure 1. Elemental analysis of PCC by XRF of the synthesized PCC 
The functioal group analysis of PCC can be seen in Figure 2. The IR spectrum of PCC in this work exhibits two characteristic carbonates bands: $v_{2}$ at $856 \mathrm{~cm}^{-1}$ and $v_{3}$ at 1489 $\mathrm{cm}^{-1}$ (Figure 1b). The wide peak at $3448 \mathrm{~cm}^{-1}$ is assigned to $\mathrm{O}-\mathrm{H}$ stretching of hydroxyl band. As already known, at undisturbed state, the VSEPR of carbonate ion is planar with three identic symmetrically C-O bonds, associating to the $D_{3 h}$ point group which is three-fold rotational axis, a horizontal plane of symmetry and three vertical planes of symmetry at $60^{\circ}$ to one another. Among the regular vibrational form of planar carbonate ion, $v_{2}$ (C-O out-ofplane bending), $\quad v_{3} \quad$ (C-O asymmetric stretching), and $v_{4}$ (C-O planar bending) are IR active, while $v_{1}$ (C-O symmetric stretching), $v_{3}$, $v_{4}$ are Raman active (Ren et al., 2014).

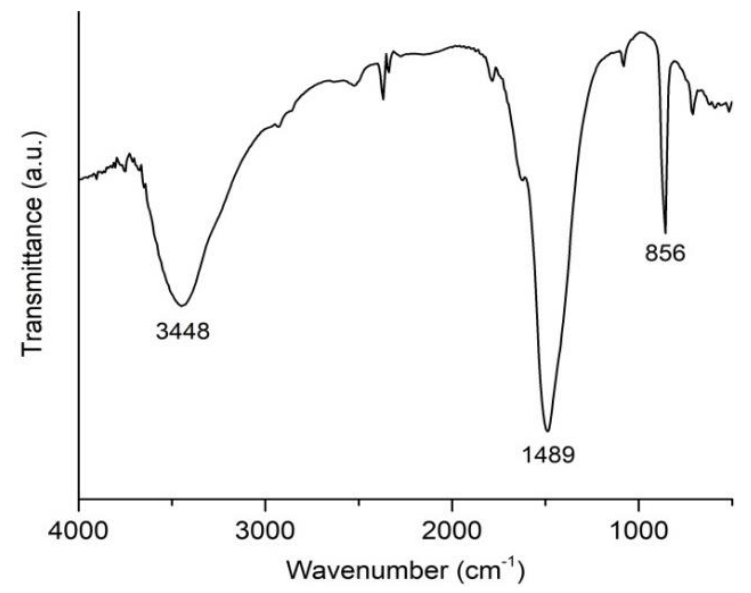

Figure 2. The IR spectra of the synthesized PCC

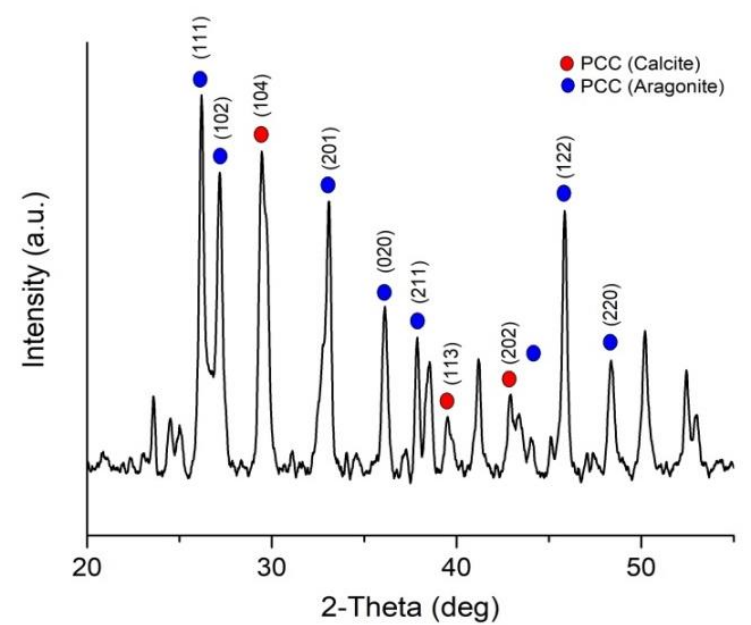

Figure 3. X-Ray diffraction pattern of the synthesized PCC

XRD characterization was aimed to determine the type of crystal of the synthesized material. Calcium carbonate crystals $\left(\mathrm{CaCO}_{3}\right.$, PCC) have three types: calcite, aragonite and veterite et al., 2020; Zou et al., 2017). Each crystal identified by different diffraction angles and Miller's indexed. The crystal form of PCC in Figure 3 is a mixture of calcite and aragonite. From the diffractogram, the calcite phase showed at $2 \theta: 29.55^{\circ}(104), 39.56^{\circ}$ (113), and $43.10^{\circ}$ (202) (Zou et al., 2017). While the aragonite phase was showed at $2 \theta$ : $26.19^{\circ}$ (111), $27.19^{\circ}$ (102), 33.01 ${ }^{\circ}$ (201), $36.05^{\circ}(020), 37.82^{\circ}(211), 45.71^{\circ}(122)$, and $48.48^{\circ}$ (220) (Elfina et al., 2020). Comparison of the peak to the International Center Data Diffraction (ICDD) No. 01-083-0577 for calcite No. 01-070-9854 for aragonite phase was presented and Table 1 . The symbol $D(\mathrm{~nm})$ is the crystallite size that determines using Scherer equation:

$$
D=\frac{k \lambda}{\beta \operatorname{Cos} \theta}
$$

Where $\beta$ (rad) is the Full Width at Half Maximum (FWHM), $k$ is the Scherer constant $(0.9-1.0), \lambda$ is the wavelength of $X$-ray source from $\mathrm{CuK} \alpha$ radiation $(0.15406 \mathrm{~nm})$, and $\theta(\mathrm{rad})$ is the peak position of Bragg angle.

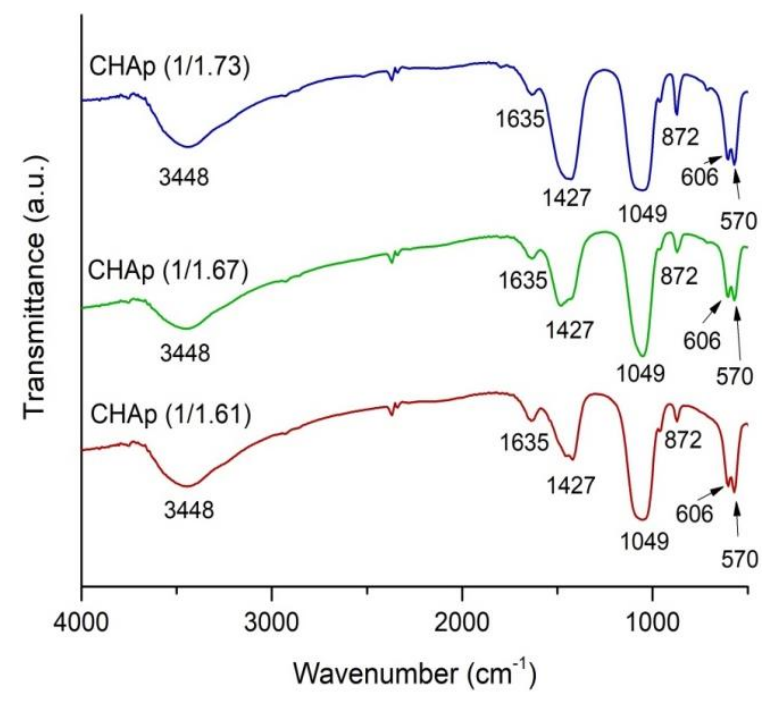

Figure 4. The IR spectra of the synthesized CHAp with $1.61,1.67$, and $1.73 \mathrm{Ca} / \mathrm{P}$ ratio

Figure 4 shows the IR spectra of CHAp that have been synthesized by the hydrothermal with the various of $\mathrm{Ca} / \mathrm{P}$ ratios. The band observed at $570 \mathrm{~cm}^{-1}$ corresponds to the $v_{4}$ bending mode of the phosphate group. Similarly, the O-P-O bending of phosphate $\left(v_{4}\right)$ 
group is observed at $606 \mathrm{~cm}^{-1}$ (Rajkumar et al., 2011). The asymmetric stretching $\left(v_{3}\right)$ mode of vibration $\mathrm{P}-\mathrm{O}$ in phosphate bonds was assigned to the band at $1049 \mathrm{~cm}^{-1}$. The observed bands at 872 and $1427 \mathrm{~cm}^{-1}$ denote the $\mathrm{HPO}_{4}{ }^{2-}$ in characteristic HA with deficient calcium refers to non-stoichiometric CHAp and the symmetric-asymmetric stretching modes of C$\mathrm{O}$ bonds of carbonates groups, respectively (Lü et al., 2007; Youness et al., 2017). However, the peak at $872 \mathrm{~cm}^{-2}$ was also attributed as a carbonate band according other scholars (Gieroba et al., 2021; Reyes-Gasga et al., 2013; Shaltout et al., 2011). The broad peaks spread over the range between 3387-3435 and $1635 \mathrm{~cm}^{-1}$ reveals the superposition of absorption because of the stretching mode of surface hydroxyl groups and adsorbed water molecules (Basuki et al., 2021; Lak et al., 2008).

Table 1. The comparison of characteristic peak of PCC with the calcite and aragonite databease

\begin{tabular}{|c|c|c|c|c|c|c|c|c|}
\hline \multicolumn{3}{|c|}{ This work } & \multicolumn{2}{|c|}{ Calcite databese } & \multicolumn{2}{|c|}{ Aragonite database } & \multirow{2}{*}{$\begin{array}{l}\text { Crystal } \\
\text { Phase }\end{array}$} & \multirow{2}{*}{$\begin{array}{l}\text { Miller } \\
\text { index }\end{array}$} \\
\hline $2 \theta\left(^{\circ}\right)$ & $D(\mathrm{~nm})$ & $\beta(\mathrm{rad})$ & $2 \theta$ & $\mathrm{D}(\mathrm{nm})$ & $2 \theta$ & $\mathrm{D}(\mathrm{nm})$ & & \\
\hline 26.19 & 22 & 0.3788 & - & - & 26.22 & 23 & aragonite & 111 \\
\hline 27.19 & 16 & 0.5112 & - & - & 27.22 & 22 & aragonite & 102 \\
\hline 29.55 & 16 & 0.5232 & 29.41 & 20 & - & - & calcite & 104 \\
\hline 33.01 & 16 & 0.5105 & - & - & 33.15 & 28 & aragonite & 201 \\
\hline 36.05 & 25 & 0.3369 & - & - & 36.17 & 21 & aragonite & 020 \\
\hline 37.82 & 34 & 0.2460 & - & - & 37.90 & 25 & aragonite & 211 \\
\hline 39.56 & 21 & 0.4097 & 39.41 & 25 & - & - & calcite & 113 \\
\hline 43.10 & 11 & 0.8200 & 43.16 & 24 & - & - & calcite & 202 \\
\hline 45.71 & 27 & 0.3179 & - & - & 45.86 & 24 & aragonite & 122 \\
\hline 48.48 & 24 & 0.3670 & - & - & 48.46 & 22 & aragonite & 220 \\
\hline
\end{tabular}

Table 2. The comparison of synthesized CHAp in this work with the CHAp in literature

\begin{tabular}{|c|c|c|c|c|c|c|c|}
\hline \multirow[b]{2}{*}{ Material } & \multicolumn{6}{|c|}{ Assignment $\left(\mathrm{cm}^{-1}\right)$} & \multirow[b]{2}{*}{ References } \\
\hline & $\mathbf{O H}^{-}$ & $\mathbf{H}_{2} \mathbf{O}$ & $\mathrm{CO}_{3}{ }^{2-}$ & $\mathrm{PO}_{4}{ }^{3-}$ & $\begin{array}{l}\mathrm{CO}_{3}{ }^{2-} / \\
\mathrm{HPO}_{4}{ }^{2-}\end{array}$ & $\mathrm{PO}_{4}{ }^{3-}$ & \\
\hline Standard HAp & 3570 & $\begin{array}{c}1620- \\
1635\end{array}$ & $\begin{array}{l}1400- \\
1470\end{array}$ & $\begin{array}{c}1040-1090 \\
960\end{array}$ & 874 & 603,565 & $\begin{array}{l}\text { Lü et al. } \\
\text { (2007) }\end{array}$ \\
\hline $\begin{array}{l}\text { HAp from } \\
\text { human teeth }\end{array}$ & 3569 & 1633 & - & $\begin{array}{c}1089,1045 \\
960\end{array}$ & - & 601,568 & $\begin{array}{l}\text { Lü et al. } \\
\text { (2007) }\end{array}$ \\
\hline HAp powder & $\begin{array}{c}3570 \\
633\end{array}$ & - & - & 1043 & - & $601,569$. & $\begin{array}{c}\text { Safari Gezaz et } \\
\text { al. (2019) }\end{array}$ \\
\hline $\begin{array}{l}\text { HAp coated } \\
\text { Ge crystal }\end{array}$ & 3570 & 1656 & 1446 & 1098,962 & - & - & $\begin{array}{l}\text { Gieroba et al. } \\
\quad(2021)\end{array}$ \\
\hline $\begin{array}{l}\text { HAp from } \\
\text { dental enamel }\end{array}$ & 633 & 1640 & 1445 & $\begin{array}{c}1090-1032 \\
960\end{array}$ & 870 & $600-500$ & $\begin{array}{l}\text { Reyes-Gasga } \\
\text { et al. (2013) }\end{array}$ \\
\hline $\begin{array}{l}\text { HAp from } \\
\text { natural source }\end{array}$ & 3567 & 1645 & 1446 & 1035 & 871 & 617 & $\begin{array}{l}\text { Shaltout et al. } \\
\qquad(2011)\end{array}$ \\
\hline $\begin{array}{l}\text { HAp by } \\
\text { mechano- } \\
\text { chemical } \\
\text { synthesis }\end{array}$ & 3570 & 1620 & 1470 & 1055 & 875 & 605,560 & $\begin{array}{l}\text { Youness et al. } \\
\quad(2017)\end{array}$ \\
\hline $\begin{array}{l}\text { HAp from } \\
\text { Rebon shrimp }\end{array}$ & 3448 & 1635 & 1427 & 1049 & 872 & 606,570 & This work \\
\hline
\end{tabular}


Compared to the IR spectrum of CHAp, the carbonate band at $1489 \mathrm{~cm}^{-1}$ in PCC spectrum was shifted into $1427 \mathrm{~cm}^{-1}$ in CHAp spectra of all $\mathrm{Ca} / \mathrm{P}$ ratios (Figure 4). In addition, the intensity at $1427 \mathrm{~cm}^{-1}$ increased with the increasing of $\mathrm{Ca} / \mathrm{P}$ ratio. This might be attributed to substituting of $\mathrm{CO}_{3}{ }^{2-}$ with $\mathrm{PO}_{4}{ }^{3-}$ or $\mathrm{OH}^{-}$in the apatite for charge compensation. In present work, the $\mathrm{CO}_{3}{ }^{2-}$ peak can be observed in the spectra of synthesized CHAp samples in all $\mathrm{Ca} / \mathrm{P}$ ratios. This is due to $\mathrm{CO}_{3}{ }^{2-}$ caused from the rest of carbonate in $\mathrm{PCC}$ or from $\mathrm{CO}_{2}$ in air by calcination during synthesis process. It was also observed that the intensities of the phosphate band are increase with the increasing of the $\mathrm{Ca} / \mathrm{P}$ ratio. The comparison of synthesized CHAp in this work with the CHAp in literature was listed in Table 2.

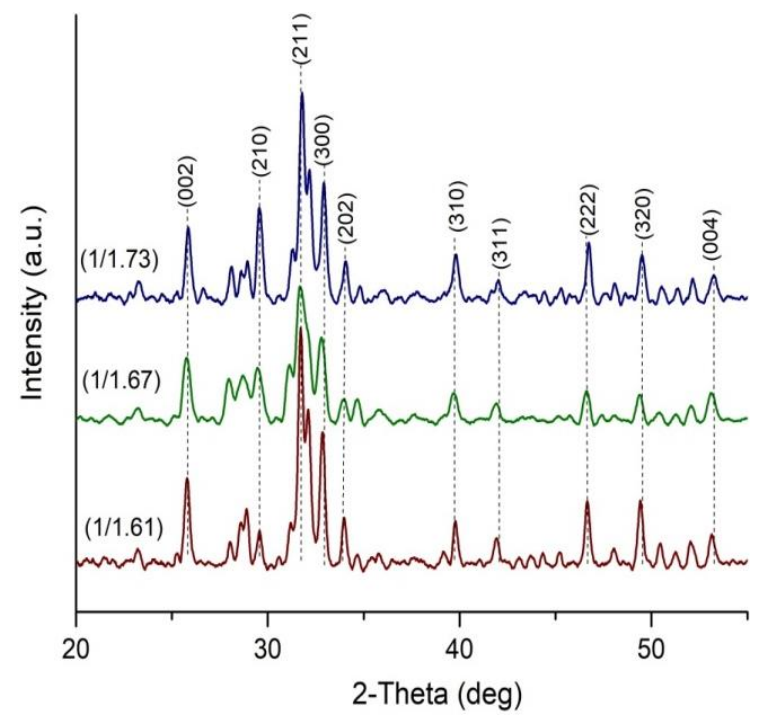

Figure 5. X-Ray diffraction pattern of the synthesized CHAp with $1.61 ; 1.67$; and $1.73 \mathrm{Ca} / \mathrm{P}$ ratio

The XRD patterns of CHAp with the 1.61; 1.67; and $1.73 \mathrm{Ca} / \mathrm{P}$ ratios are shown in Figure 5. All the observed peak are readily indexed and compared with the reported value of hexagonal CHAp database (JCPDS file no. 090432). The main peaks indexed to (002) at about 26, broad and overlapped peaks of (210), (211), (300), (202) at 31-32, (310) and (311) at approximately $40,(222)$ at about $47,(320)$ at 50 and (004) at 54 indicate that the synthesized materials are CHAp (Aneem et al., 2019). After comparing with biological apatites from Aneem et al. (2019), it was concluded that the synthesized apatites resembled bone like apatite and indicates carbonate incorporation in the apatite crystal. There are no obvious peaks for the presence of other phases of CHAp that indicates the purity of the synthesized CHAp. The high intensity and broad width of the bands showed that the particles were highly crystalline and nano scale size, respectively.

The calculated lattice parameters are listed in Table 3. Average crystallite sizes $(D)$ of samples with $\mathrm{Ca} / \mathrm{P}$ ratios $1.61 ; 1.67$; and 1.73 were calculated from XRD pattern by Scherer equation to be 26.3, 18.6, and 25.3, respectively. This shows that the higher $\mathrm{Ca} / \mathrm{P}$ will relatively produce the smaller crystallite size. The study of effect of $\mathrm{Ca} / \mathrm{P}$ ratio on the crystallite size by Syafaat \& Yusuf (2018) reveal the similar result. On the other hand, the crystallinity of the samples was decrease with the increasing of $\mathrm{Ca} / \mathrm{P}$ ratios (Table 3). Further, it also decreases in the micro strain $(\varepsilon)$ and dislocation density $(\delta)$. At constant $\mathrm{pH}$, the crystal analyses showed that the higher $\mathrm{Ca} / \mathrm{P}$ ratio will decrease the crystallinity (Mekmene et al., 2009).

Figure 5 shows the as-prepared CHAp micrograph is a spherical type of characteristic crystal carbonated apatites synthesized by hydrothermal procedures (Garskaite et al., 2014). Morphological results of as-prepared CHAp particles were consistent with the lattice parameter of XRD pattern in Table 3 (18.6$26.3 \mathrm{~nm})$. All powder samples, Fig. 6(a-c), consist of agglomerates form which the shapes are identical. It is observed from particle size analysis by Origin ${ }^{\circledR}$ Software that the size of agglomerates is between 5 and $20 \mu \mathrm{m}$, and they were composed from fine particles $18-26 \mathrm{~nm}$ in size. It is evident that the microstructure of hydrothermally synthesized CHAp was formed through several stages, starting from crystallite structure of particles of $18-26 \mathrm{~nm}$ to fine subagglomerate particles up to $200 \mathrm{~nm}$, which further cluster to give agglomerates 5-20 $\mu \mathrm{m}$ in size.

The elemental analysis of synthesized CHAp in all ratios was listed in Table 4. Based on the table, the composition of $\mathrm{Ca} / \mathrm{P}$ ratios of synthesized CHAp was similar to the $\mathrm{Ca} / \mathrm{P}$ ratio in early stages of CHAp synthesis. This result indicated that the all of carbonate ion in PCC was relatively react with the phosphate ion to form CHAp. Even though, the excess calcium (carbonate) compose the higher agglomerated CHAp. 
Table 3. The calculated crystal size (D), crystallinity, micro strain $(\varepsilon)$, and dislocation density $(\delta)$ of synthesized $\mathrm{CHAp}$ for different $\mathrm{Ca} / \mathrm{P}$ ratios

\begin{tabular}{ccccc}
\hline $\mathrm{Ca} / \mathrm{P}$ ratio & $D(\mathrm{~nm})$ & Crystallinity $(\%)$ & $\varepsilon\left(\times 10^{-3}\right)$ & $\delta\left(\times 10^{-3} \mathrm{~nm}^{-2}\right)$ \\
\hline 1.61 & 26.3 & 72.1 & 11.2 & 11.6 \\
1.67 & 18.6 & 70.5 & 5.0 & 2.1 \\
1.73 & 25.3 & 68.0 & 4.1 & 2.2 \\
\hline
\end{tabular}
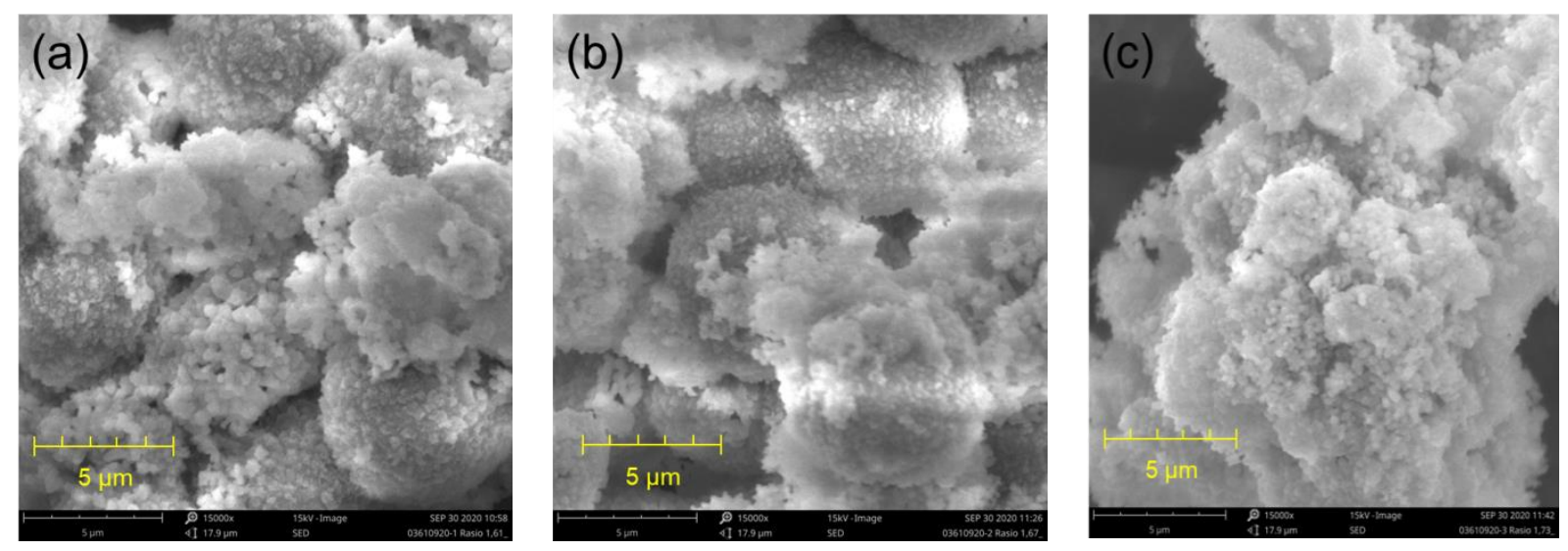

Figure 6. Characteristic microstructure by SEM of synthesized CHAp with Ca/P ratio 1.61 (a), 1.67 (b), and 1.73 (c)

Tabel 4. Elemental analysis of synthesized CHAp

\begin{tabular}{lccc}
\hline \multicolumn{1}{c}{ Elements } & $\begin{array}{c}\text { Precursor CHAp ratios } \\
\mathbf{1 / 1 . 6 1}(\mathbf{w t} \boldsymbol{)})\end{array}$ & $\begin{array}{c}\text { Precursor CHAp ratios } \\
\mathbf{1 / 1 . 6 7}(\mathbf{w t} \boldsymbol{)})\end{array}$ & $\begin{array}{c}\text { Precursor CHAp } \\
\text { ratios 1/1.73 (wt \%) }\end{array}$ \\
\hline Calcium & 8.58 & 14.91 & 6.35 \\
Phosphorus & 5.78 & 8.99 & 3.73 \\
Oxygen & 58.97 & 53.35 & 39.05 \\
Carbon & 25.86 & 21.43 & 50.18 \\
Others & 0.81 & 1.32 & 0.69 \\
Synthesized CHAp ratios & 1.49 & 1.66 & 1.71 \\
\hline
\end{tabular}

\section{CONCLUSION}

Calcium was found as the dominant element of Rebon shrimp (Acetes erythraeus) which are highly potential as the basic material of carbonated calcium hydroxyapatites. The present work investigates a detailed characterization of CHAp from Rebon shrimp (Acetes erythraeus). Spectroscopic characterization by FT-IR was assigned the characteristic CHAp band of hydroxide (3448, $\left.1635 \mathrm{~cm}^{-1}\right)$, carbonate $\left(872,1427 \mathrm{~cm}^{-1}\right)$, and phosphate $\left(1049,606,570 \mathrm{~cm}^{-1}\right)$. The XRD pattern assigned the all observed peak of CHAp are in good agreement compared to CHAp database (JCPDS file no. 09-0432) with the nano-scale size obtained by Scherer equation. The main peaks indexed to (002) at about 26, broad and overlapped peaks of (210), (211), (300), (202) at 31-32, (310) and (311) at approximately $40,(222)$ at about $47,(320)$ at 50 and (004) at 54 indicate that the synthesized materials are CHAp. It also observed that the high $\mathrm{Ca} / \mathrm{P}$ ratio will decrease the crystallinity of CHAp. The as-prepared CHAp micrograph is agglomerates spherical form with size between 5-20 nm which build up from 18-26 $\mathrm{nm}$ crystallite particles. It is obviously evidenced that the Rebon shrimp can be used as a source of calcium for CHAp production which is a candidate material of bone or dental restoring candidate.

\section{ACKNOWLEDGMENT}

The authors would like to thank the University of Jambi for funding this work through the DIPA PNBP LP2M Funding Basic Research Scheme Fiscal Year 2020 (Number: 
SP DIPA-023.17.2.677565/2020) Contract Number: 433/UN21.18/PG/SPK/2020.

\section{REFERENCES}

Aneem, T. H., Saha, S. K., Jahan, R. A., Wong, S. Y., Li, X., \& Arafat, M. T. (2019). Effects of organic modifiers and temperature on the synthesis of biomimetic carbonated hydroxyapatite. Ceramics International, 45(18), 24717-24726. https://doi.org/10.1016/j.ceramint.2019.08. 211

Anggresani, L., Sari, Y. N., \& Rahmadevi, R. (2021). Hydroxyapatite (HAp) From Tenggiri Fish Bones As Abrasive Material In Toothpaste Formula. Jurnal Kimia Valensi, 1(1), 1-9.

Azis, Y., Jamarun, N., Zultiniar, Arief, S., \& Nur, H. (2015). Synthesis of hydroxyapatite by hydrothermal method from cockle shell (Anadara granosa). Oriental Journal of Chemistry, 7(5), 798-804.

Basuki, R., Rusdiarso, B., Santosa, S. J., \& Siswanta, D. (2021). MagnetiteFunctionalized Horse Dung Humic Acid (HDHA) for the Uptake of Toxic Lead (II) from Artificial Wastewater. Adsorption Science \& Technology, 2021(5523513), 115. https://doi.org/10.1155/2021/5523513

Deb, S., \& Chana, S. (2015). Biomaterials in relation to dentistry. Biomaterials for Oral and Craniomaxillofacial Applications, 17, $1-12$.

Dorozhkin, S. V. (2011). Medical application of calcium orthophosphate bioceramics. Bio, 1(1), 1-51.

Elfina, S., Jamarun, N., Arief, S., \& Djamaan, A. (2020). Sintesis Precipitate Calsium Carbonat Sebagai Filler Pada Plastik Ramah Lingkungan. REACTOR: Journal of Research on Chemistry and Engineering, 1(1), 1-6.

Garskaite, E., Gross, K. A., Yang, S. W., Yang, T. C. K., Yang, J. C., \& Kareiva, A. (2014). Effect of processing conditions on the crystallinity and structure of carbonated calcium hydroxyapatite (CHAp). CrystEngComm, 16(19), 3950-3959. https://doi.org/10.1039/c4ce00119b

Gieroba, B., Przekora, A., Kalisz, G., Kazimierczak, P., Song, C. L., Wojcik, M.,
Ginalska, G., Kazarian, S. G., \& SrokaBartnicka, A. (2021). Collagen maturity and mineralization in mesenchymal stem cells cultured on the hydroxyapatite-based bone scaffold analyzed by ATR-FTIR spectroscopic imaging. Materials Science and Engineering C, 119(October 2020), 111634. https://doi.org/10.1016/j.msec.2020.11163 4

Hanura, A. B., Trilaksani, W., \& Suptijah, P. (2017). Karakterisasi Nanohidroksiapatit Tulang Tuna Thunnus sp Sebagai Sediaan Biomaterial. Jurnal Ilmu Dan Teknologi Kelautan Tropis, 9(2), 619-629.

Hien, V. D., Huong, D. Q., \& Bich, P. T. N. (2010). Study of the Formation of Porous Hydroxyapatite Ceramics from Corals via Hydrothermal Process. Journal of Chemistry, 48(5), 591-596.

Lak, A., Mazloumi, M., Mohajerani, M., Kajbafvala, A., Zanganeh, S., Arami, H., \& Sadrnezhaad, S. K. (2008). SelfAssembly of Dandelion-Like Hydroxyapatite Nanostructures Via Hydrothermal Method. Journal of the American Ceramic Society, 91(10), 32923297.

LeGeros, R. Z. (2008). Calcium phosphate-based osteoinductive materials. Chemical Reviews, 108(11), 4742-4753.

Lü, X. Y., Fan, Y. Bin, Gu, D., \& Cui, W. (2007). Preparation and Characterization of Natural Hydroxyapatite from Animal Hard Tissues. Key Engineering Materials, 342343 , 213-216. https://doi.org/10.4028/www.scientific.net/ kem.342-343.213

Matinlinna, J. P. (2013). Processing and bonding of dental ceramics. In Non-metallic biomaterials for tooth repair and replacement (pp. 129-160). Elsevier.

Mekmene, O., Quillard, S., Rouillon, T., Bouler, J. M., Piot, M., \& Gaucheron, F. (2009). Effects of $\mathrm{pH}$ and $\mathrm{Ca} / \mathrm{P}$ molar ratio on the quantity and crystalline structure of calcium phosphates obtained from aqueous solutions. Dairy Science and Technology, 89(3-4), 301-316. https://doi.org/10.1051/dst/2009019

Odusote, J. K., Danyuo, Y., Baruwa, A. D., \& Azeez, A. A. (2019). Synthesis and 
characterization of hydroxyapatite from bovine bone for production of dental implants. Journal of Applied Biomaterials and Functional Materials, 17(2). https://doi.org/10.1177/228080001983682 9

Okada, M., \& Matsumoto, T. (2015). Synthesis and modification of apatite nanoparticles for use in dental and medical applications. Japanese Dental Science Review, 51(4), 85-95.

https://doi.org/10.1016/j.jdsr.2015.03.004

Pajor, K., \& Pajchel, L. (2019). Hydroxyapatite and Fluorapatite in Conservative. Materials, 12(2683), 1-16.

Permatasari, A. P., Yanuar, M., \& Nahzi, I. (2016). Kekasaran permukaan resin-modified glass ionomer cement setelah perendaman dalam air sungai (penelitian menggunakan air sungai desa anjir pasar, barito kuala ,kalimantan selatan). Dentino Jurnal Kedokteran Gigi, I(2), 164-168.

Rajkumar, M., Meenakshisundaram, N., \& Rajendran, V. (2011). Development of nanocomposites based on hydroxyapatite/sodium alginate: Synthesis and characterisation. Materials Characterization, 62(5), 469-479. https://doi.org/10.1016/j.matchar.2011.02. 008

Ren, F., Ding, Y., \& Leng, Y. (2014). Infrared spectroscopic characterization of carbonated apatite: A combined experimental and computational study. Journal of Biomedical Materials Research Part A: An Official Journal of The Society for Biomaterials, The Japanese Society for Biomaterials, and The Australian Society for Biomaterials and the Korean Society for Biomaterials, 102(2), 496-505.

Reyes-Gasga, J., Martínez-Piñeiro, E. L., Rodríguez-Álvarez, G., Tiznado-Orozco, G. E., García-García, R., \& Brès, E. F. (2013). XRD and FTIR crystallinity indices in sound human tooth enamel and synthetic hydroxyapatite. Materials Science and Engineering C, 33(8), 45684574 .

https://doi.org/10.1016/j.msec.2013.07.014

Safari Gezaz, M., Mohammadi Aref, S., \& Khatamian, M. (2019). Investigation of structural properties of hydroxyapatite/ zinc oxide nanocomposites; an alternative candidate for replacement in recovery of bones in load-tolerating areas. Materials Chemistry and Physics, 226(July 2018), 169-176. https://doi.org/10.1016/j.matchemphys.201 9.01.005

Shaltout, A. A., Allam, M. A., \& Moharram, M. A. (2011). FTIR spectroscopic, thermal and XRD characterization of hydroxyapatite from new natural sources. Spectrochimica Acta - Part A: Molecular and Biomolecular Spectroscopy, 83(1), 56-60. https://doi.org/10.1016/j.saa.2011.07.036

Sianipar, J. S. (2016). Sintesis Hidroksiapatit melalui Precipitated Calcium Carbonate (PCC) Kulit Kerang Darah dengan Metode Hidrotermal. Riau University.

Sulistioso, G. S., Deswita, D., Wulanawati, A., \& Romawati, A. (2012). Sintesis Hidroksiapatit Berpori dengan Porogen Kitosan dan Karakterisasinya. Jurnal Kimia Dan Kemasan, 34(1), 219-224.

Sulistiyono, P., Herawati, D. M. D., \& Arya, I. F. D. (2017). Rebon Shrimp Powder Addition Influence to Nutritional Values, Organoleptic Properties and Acceptance of Supplementary Food by Children Aged 45 Years Old. Kesmas: Jurnal Kesehatan Masyarakat Nasional (National Public Health Journal), 11(4), 168-172.

Syafaat, F. Y., \& Yusuf, Y. (2018). Effect of ca:P concentration and calcination temperature on hydroxyapatite (HAp) powders from quail eggshell (coturnix coturnix). International Journal of Nanoelectronics and Materials, 11, 51-58.

Vallet-Regi, M. (2014). Bio-ceramics with clinical applications. John Wiley \& Sons.

Vishwakarma, A., Sharpe, P., Shi, S., \& Ramalingam, M. (2014). Stem cell biology and tissue engineering in dental sciences. Academic Press.

Xie, C., Lu, H., Li, W., Chen, F.-M., \& Zhao, Y.-M. (2012). The use of calcium phosphatebased biomaterials in implant dentistry. Journal of Materials Science: Materials in Medicine, 23(3), 853-862.

Youness, R. A., Taha, M. A., Elhaes, H., \& Ibrahim, M. (2017). Molecular modeling, FTIR spectral characterization and mechanical properties of carbonated- 
hydroxyapatite prepared by mechanochemical synthesis. Materials Chemistry and Physics, 190, 209-218. https://doi.org/10.1016/j.matchemphys.201 7.01.004
Zou, Z., Bertinetti, L., Politi, Y., Fratzl, P., \& Habraken, W. J. E. M. (2017). Control of polymorph selection in amorphous calcium carbonate crystallization by poly (aspartic acid): two different mechanisms. Small, 13(21), 1603100. 